\title{
Erythroid Transcription Factor
}

National Cancer Institute

\section{Source}

National Cancer Institute. Erythroid Transcription Factor. NCI Thesaurus. Code C17493.

Erythroid transcription factor ( $413 \mathrm{aa}, \sim 43 \mathrm{kDa}$ ) is encoded by the human GATA1 gene.

This protein is involved in transcription and erythropoiesis. 